series of prominent oblong tubercles. Heel without prominence. Very dark-coloured, a more or less distinct small white spot on the middle of the side; each toe generally with a narrow white ring.

Two males, 10 inches long, the tail measuring exactly one half.

3. Descriptions of new Species of Rhopalocera from Central and South America. By F. DuCane Godman, F.Z.S., and Osbert Salvin, F.R.S.

[Received January 29, 1879.]

(Plate XIV.)

The following descriptions are all taken from specimens in our collection; they relate to species many of which have long remained unnamed; to these we have added descriptions of some recent acquisitions. Figures of all the Central-American species will shortly be published.

\title{
Eutresis hyspa.
}

o . Exp. 3.9 in. Allied to E. hyperia, D. \& H. (Gen. Diurn. Lep. i. p. 112, Suppl. Pl. f. 2): but the primaries are diaphanous where in $\boldsymbol{E}$. hyperia they are fulvous; the secondaries also are almost diaphanous, the inner edge of the dark margin, especially near the anal angle, the spot at the end of the cell, and the nervules alone being fulvous. To $E$. theope (nob. P. Z. S. 1877, p. 60) it is more nearly allied, differing chiefly in the broader margin of the secondaries and the greater restriction of the fulvous on those wings.

Hab. Ecuador, Jorge, Guadalquiza (Buckley).

Athesis demylus.

o. Exp. 3 in. Nearly allied to Dircenna dercyllidas, Hew. (Trans. Ent. Soc. ser. 3. ii. p. 248, pl. 16. f. 4), of which it is a more southern race. The transverse markings of the primaries are very narrow, the whole of the wing being diaphanous with the exception of the dark margins, the remains of the transverse bands being represented by the dark nervules. The transverse band of the secondaries is narrower, as well as the outer margin.

$H a b$. Southern Ecuador.

We have two male specimens of this species which were sent from the confines of Ecuador and Peru some years ago. We have hesitated to describe it before being convinced of the constancy of its differential characters.

\section{Melinata hicetas.}

§. Exp. $3 \cdot 4$ in. Allied to M. maelus (Hew. Ex. Lep., Mechanites, t. 3. f. 6), but differing in the absence of yellow in the cross band of the primaries, this portion of the wing being of the same colour as the base. The apex is black, enclosing three yellowish 


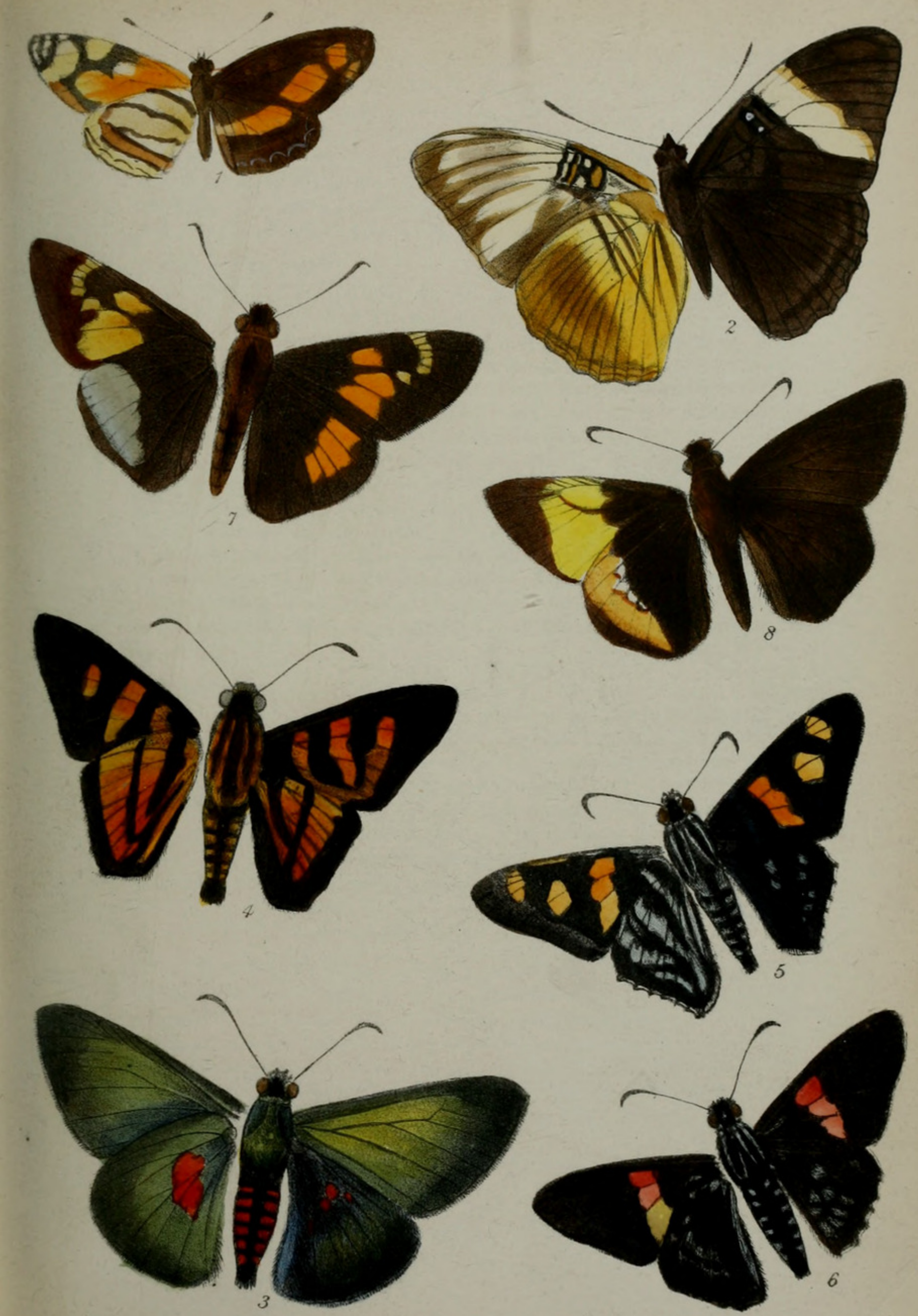

RHFRippon lith 

tawny spots, the secondaries are crossed by a median and a submarginal bands, which are divided by the tawny submedian branches; these bands in some specimens are almost confluent.

Hab. Yquitos, Upper Amazon (Whitely).

This is one of the numerous forms of $M$. maelus found in the Upper Amazon and Lower Napo. Having six specimens from these countries all closely resembling one another, we think it necessary that this form should bear a name.

\section{Melinea Cydon.}

б. Exp. $3 \cdot 3$ in. Allied to M. pardalis (Bates, Trans. Linn. Soc. xxiii. p. 552), but differing in the absence of the yellow cross belt of the primaries, the only yellow markings on the wing being restricted to a subapical series of three spots. The tawny brown markings of both wings are rather more clearly defined than in $M$. pardalis; and the central black cross bar of the secondaries is generally distinct from the black outer margin.

Hab. Tabatinga (Bates); Pebas (Hauxwell); Yquitos (Whitely).

This is the race alluded to by Mr. Bates under his description of $M$. pardalis. At that time he did not seem to have considered it sufficiently distinct to separate it; but since then additional examples have come to hand, which point to the conclusion that this race is as well-defined as $M$. pardalis itself. The same degree of local differentiation is to be seen in Ceratinia tigrina as compared with C. Auonia. In Heliconius pardalinus a similar state of things is to be found.

\section{Eresia laias. (Plate XIV. fig. 1.)}

Exp. 2 in. Allied to E. carme (Doubl. and Hew.), differing in the arrangement of the spots of the primaries: a large patch of fulvous occupies the apex of the wing, between which and the inner margin lies a larger oval patch, its axis parallel to the outer margin; beyond the cell is a small fulvous spot, obsolete in some specimens. Beneath the colour-pattern is much as in $\boldsymbol{E}$. carme; but the fulvous base of the primaries extends interruptedly almost to the outer margin, but does not include the spots in the apex. In $E$. carme there are distinct spots near the anal angle.

Hab. Frontino, Columbia (T. K. Salmon).

ADELPHA HYPSENOR.' (Plate XIV. fig. 2.)

Exp. $2 \cdot 9$ in. Allied to A. lara (Hewitson), but differing on the upperside in having the transverse extra-cellular band on the primaries white, instead of red; this white band is divided by dark nervules, and on its outer edge especially, where it approaches the outer margin, is tinged with fulvous. Beneath, the band of the primaries is white instead of pink as in A. lara, and the basal half of the secondaries is yellower.

Hab. Frontino, Columbia (T. K. Salmon).

PyrRhopyga rufinucha.

Exp. $2 \cdot 4$ in. Body bluish black; palpi black; a rufous spot at the 
back of the head, and one on the thorax beneath; the outer margin of secondaries narrowly red.

Hab. Bolivia (Buckley).

Obs. Differs from T. hygieia and all its allies in having a red nuchal patch.

\section{Pyrrhopyga errata. (Plate XIV. fig. 3.)}

Exp. 3 in. Body greenish black, abdomen with six rufous bands on either side : wings bronzy-green; secondaries rather darker, with a discocellular and three adjoining spots rufous. Beneath, both wings bronzy green, three spots forming a patch in the middle of the secondaries rufous.

Hab. Pueblo Viejo, Sierra Nevada de Santa Marta (Simons).

Obs. Apparently allied to T. hygieia, but differing considerably both in colour and markings. We have but a single specimen of this fine species, one of Mr. Simons's recent discoveries.

\section{Pyrrhopyga rufipectus.}

Exp. $2 \cdot 5$ in. Body greenish black, head and palpi black, a rufous pateh on the thorax beneath; wings as in $T$. hygieia.

Hab. Ecuador, Rio Topo (Buckley).

Obs. Differs from T. hygieia in having black palpi and a rufous patch on the thorax beneath.

\section{Pyrrhopyga variegaticeps.}

Exp. $2 \cdot 4$ in. Body black, head between the eyes with three indistinct white bars, wings rich metallic blue, darker on the secondaries towards the outer margin and anal angle. Cilia of the outer margin of secondaries red.

Hab. Costa Rica (Rogers).

Obs. Allied to T. hygieia (Feld. Reise Nov. Lepid. iii. p. 506, t. 70. f. 1); differing in the white markings of the head; the palpi are black instead of red, and the red outer margin of the secondaries narrower.

Pyrrhopyga minthe. (Plate XIV. fig. 4.)

Exp. 2.6 in. Allied to T. pityusa, Hew. (Exot Butt. Pyrrh. ii. f. 11); but differs in the proximal band of the primaries being obsolete and the apical spot being wholly absent; the dark line which crosses the secondaries from the middle of the costa in the direction of the anal angle is much narrower in the present species.

Hab. Rio Topo, Ecuador (Buckley).

\section{Pyrrhopyga eupheme. (Plate XIV. fig. 5.)}

Exp. $2 \cdot 4$ in. Wings black ; primaries crossed through the middle from the subcostal to the submedian nervures by a reddish yellow band; in the apex is an oval yellow trifid spot, between which and the the band is a similar bifid spot; the secondaries are considerably produced at the anal angle, and are crossed by two obsolete bluish 
bands. Beneath, primaries as above, secondaries crossed with three blue-grey bands, the submarginal one being somewhat broken.

Hab. Cosnipata, Peru (Whitely); Apolobamba, Bolivia (Pearce).

Obs. Allied to $\boldsymbol{P}$. iphinous, Latr.; differing chiefly in the more elongated hind wings, the narrower cross band of the primaries, and the greater breadth of the blue-grey bands of the secondaries beneath.

\section{Pyrrhopyga malis. (Plate XIV. fig. 6.)}

Exp. $2 \cdot 5$ in. Body and wings black; primaries with a central red band crossing the cell from the subcostal to the submedian nervure; two obsolete bluish bands parallel to the outer margin of the secondaries. Beneath, the lower third of the red band of the primaries is yellow; three greyish-blue obsolete bands cross the secondariesone near the base, one through the middle, and one parallel to the outer margin.

Hab. Frontino, Antioquia (Salmon).

Obs. Allied to P. nurscia, Swains., but differs in having the secondaries beneath crossed with obsolete blue-grey bands, instead of the whole inner area of the wing being nearly uniformly of that colour.

\section{Pyrrhopyga erythrosticta.}

Allied to P. maculosa, Hew. (Tamyris agathon, Feld. Reise Nov. Lep. iii. t. 70. f. 2, 3). Differing in being browner, in having a rufous spot on the primaries in the angle between the median and submedian nervures, and in the narrower black margin to the secondaries beneath.

$H a b$. Chontales, Nicaragua (Belt); Veragua (Arcé).

Obs. Certainly a close ally of $P$. maculosa; but all our specimens show the above differences are constant.

\section{Myscelus belti.}

o. Exp. $2 \cdot 2$ in. Allied to M. epimachia H.-S. (Hew. Exot. Butt. Pyrrhopyga, iv. f. 26, 27), but rather deeper in colour above, and there are no white marks on the cilia of the secondaries. Beneath, the whole of the base of the primaries inside the inner hyaline spot is yellow, the black transverse band being absent, the inner black band of the secondaries is also absent, there being merely an obsolete black spot between the median and submedian nervures. In the female the secondary wings above are almost uniform rusty brown; beneath, the base of both wings is yellow, that of the secondaries including a few black spots : there are no black bands on the wings; but the distal half is uniform black.

Hab. Chontales, Nicaragua (Belt \& Janson); Polochic valley, Guatemala (Hague).

Obs. In the late Mr. Belt's collection several specimens of this species occur. Its nearest ally is no doubt M. epimachia as represented by Hewitson; but the differences pointed out above seem associated with its distinct habitat, and thus the species requires separation. We have long had a single Guatemalan example in our collection, 


\section{$2 \mathrm{BHL}$ Biodiversity Heritage Library}

Godman, Frederick Du Cane and Salvin, Osbert. 1879. "3. Descriptions of new Species of Rhopalocera from Central and South America." Proceedings of the Zoological Society of London 1879, 150-155.

https://doi.org/10.1111/j.1096-3642.1879.tb02642.x.

View This Item Online: $\underline{\text { https://www.biodiversitylibrary.org/item/90453 }}$

DOI: https://doi.org/10.1111/j.1096-3642.1879.tb02642.x

Permalink: https://www.biodiversitylibrary.org/partpdf/73395

\section{Holding Institution}

Natural History Museum Library, London

\section{Sponsored by}

Natural History Museum Library, London

\section{Copyright \& Reuse}

Copyright Status: Public domain. The BHL considers that this work is no longer under copyright protection.

This document was created from content at the Biodiversity Heritage Library, the world's largest open access digital library for biodiversity literature and archives. Visit BHL at https://www.biodiversitylibrary.org. 